\title{
Genetic basis of keloid formation in wounds after cardiac surgery
}

\author{
Przemysław Kulawczuk ${ }^{1}$, Norbert Czapla ${ }^{1}$, Agnieszka Bińczak-Kuleta², Krzysztof Safranow ${ }^{3}$, \\ Anna Jaworska-Kulawczuk ${ }^{4}$, Dominika Gajewska ${ }^{5}$, Karolina Agata $^{5}$, Miłosz Brykczyński $^{5}$, Piotr Bargiel ${ }^{5}$ \\ ${ }^{1}$ Clinic of Plastic Surgery, Endocrine and General Surgery, Pomeranian Medical University in Szczecin, Poland \\ ${ }^{2}$ Department of Laboratory Diagnostics and Molecular Medicine, Pomeranian Medical University in Szczecin, \\ Poland \\ ${ }^{3}$ Department of Biochemistry, Department of Biochemistry and Medical Chemistry, Pomeranian Medical University in Szczecin, \\ Poland \\ ${ }^{4}$ Clinic of Haematology, Pomeranian Medical University in Szczecin, Poland \\ ${ }^{5}$ Students Research Circle at Clinic of Plastic Surgery, Endocrine and General Surgery, Pomeranian Medical University in Szczecin, \\ Poland
}

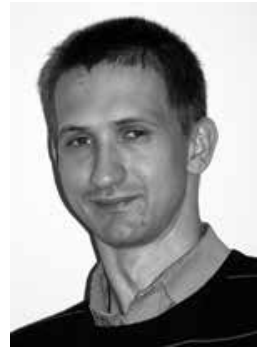

Kardiochirurgia i Torakochirurgia Polska 2014; 11 (3): 273-277

\begin{abstract}
Keloid disease is the abnormal formation of scar tissue in genetically predisposed people. Among many genes which may be related to the development of keloids, transforming growth factor $\beta 1$ (TGF- $\beta 1$ ) is one of the most mentioned. It encodes cytokinin, which is responsible for the production of extracellular matrix and takes part in healing. Any abnormalities which arise during synthesis of the protein as a result of polymorphism or gene mutation may be the cause of healing disorders (scarring of the body); thus it is responsible for the development of keloids. The objective of this study is to determine the single nucleotide polymorphism of the gene TGF- $\beta 1$, at the position -509(rs1800469)509, to compare the obtained results in the form of three different genotypes within the analysed group (keloids) and within the control group (healthy scars), and to analyse the correlation between obtained genotypes and the occurrence of keloid disease.

Seventy-three patients after cardiac surgery with scars on their sternums were examined ( 22 women and 51 men) in the age group from 38 to 84 years. Two groups of patients were distinguished: 37 with keloids and 36 with healthy scars. DNA taken from patients was analysed and polymorphism C(-509)T of the gene TGF- $\beta 1$ was determined.

On the basis of the study it was found that the allele $T$ in the position -509 of the gene TGF- $\beta 1$ is associated with a lower risk of keloid formation regardless of age and gender.

Key words: keloid scarring, keloid disease, gene polymorphism, gene mutation.
\end{abstract}

\section{Streszczenie}

Choroba keloidowa polega na nieprawidłowym tworzeniu się tkanki bliznowej u osób genetycznie predysponowanych. Wśród wielu genów, które mogą mieć związek z rozwojem keloidu, jednym z najczęściej wymienianych jest gen kodujący transformujący czynnik wzrostu $\beta 1$ (TGF- $\beta 1$ ). Koduje on cytokininę odpowiedzialną za tworzenie macierzy pozakomórkowej i uczestniczy w procesie gojenia. Wszelkie nieprawidłowości pojawiające się w czasie syntezy białek w wyniku polimorfizmów lub mutacji genów mogą być przyczyną zaburzeń gojenia i powstawania blizn na ciele, powodując rozwój keloidów. Celem tej pracy jest zbadanie jednonukleotydowego polimorfizmu genu TGF- $\beta 1$ w pozycji -509(rs1800469)509 i porównanie uzyskanych wyników w formie trzech różnych genotypów w ramach grupy badanej (keloidy) i grupy kontrolnej (zdrowe blizny) oraz analiza korelacji pomiędzy uzyskanymi genotypami i występowaniem keloidów.

Badaniem objęto 73 pacjentów po operacjach chirurgicznych z bliznami na mostku: 22 kobiety i 51 mężczyzn w wieku od 38 do 84 lat. Wyróżniono dwie grupy: 37 pacjentów z keloidami oraz 36 pacjentów ze zdrowymi bliznami. Przebadano próbki DNA pacjentów i ujawniono polimorfizm C(-509)T genu TGF- $\beta 1$. Na podstawie badania wykazano, że allel T w pozycji (-509) genu TGF- $\beta 1$ związany jest z niższym ryzykiem powstawania keloidów niezależnie od wieku i płci.

Słowa kluczowe: blizny keloidowe, choroba keloidowa, polimorfizmy genów, mutacje genowe. 


\section{Introduction}

Keloid (keloid disease) is a mild form of skin neoplasm which appears as a result of abnormal wound healing. It arises from the excessive accumulation of extracellular matrix in the forming scar and it often extends beyond the area of the primary skin lesion [1-5]. The cause of the disease has not been explained yet. It concerns predisposed persons in whom, as a result of injury or surgery, symptomatic, extensive, unsightly and disfiguring scars may develop. The scars cause disfigurement or in extreme cases organ dysfunction. Family history of keloids and more frequent occurrence of the disease in some races, ethnic groups and in twins indicate that there is a genetic basis $[1,6,17]$. Many reports of keloid disease linked with genetic defects and related connective tissue such as Ehlers-Danlos syndrome, Goeminne syndrome, Rubinstein-Taybi syndrome or Dupuytren's contracture $[2,7-10,17]$ can be found in the scientific literature. In the genetic defects with mutations, one or several genes may be responsible for the formation of keloids. TGF- $\beta 1$ (transforming growth factor $\beta 1$ ), a gene located on chromosome 19 which encodes the cytokine TGF- $\beta 1$, is one of the most frequently mentioned among many genes that may have a key role in the formation of keloids. Transforming growth factor $\beta 1$ as one of the three isoforms of the protein (TGF- $\beta 1,-\beta 2$ and $-\beta 3$ ) [11-13, 17] has a key role in the wound healing processes $[14,15]$ and therefore all the irregularities of the cytokine result-

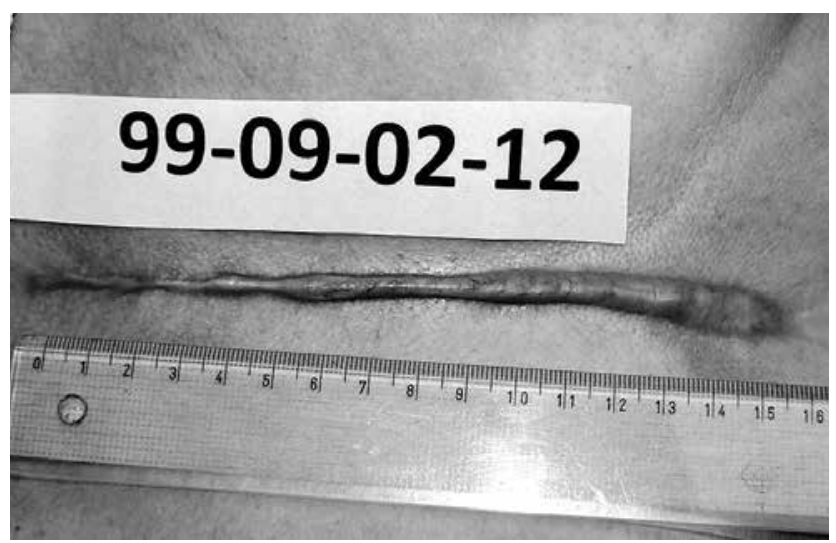

Fig. 1. Keloid

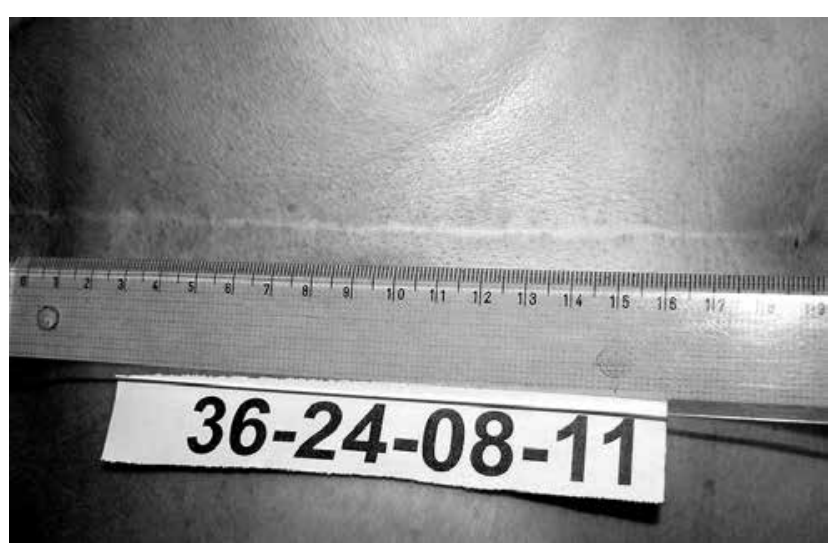

Fig. 2. Healthy scar ing from gene polymorphism or mutation of TGF- $\beta 1$ may be a direct cause of keloid disease development.

\section{Aim of the study}

The aim of the study was to investigate the polymorphism C(-509)T in the promoter region of the TGF- $\beta 1$ gene (rs1800469) among patients with a healthy scar and those with a keloid and to analyse the relationship between genotypes and the occurrence of keloid disease.

\section{Material and methods}

One hundred and eleven people were invited to participate in the study. The people were treated between 2009 and 2010 when surgical closure was carried out. Within the group of patient enrolled in the study 50 people with keloids (Fig. 1) were distinguished and 50 people with healthy scars (Fig. 2) formed a control group.

The eligibility of patients in each group was determined using the Vancouver Scar Scale assessing colour, elasticity and convexity of scars based on the subjective experience of a disease, i.e. pain, burning, itching (Tables I and II).

The minimum total number of points that can be achieved during the test is 0 points. The maximum is 16 points. Patients enrolled in the control group (healthy scar) obtained a score $\leq 3$ points, whereas patients with a score $\geq 9$ points were enrolled in the study group (keloids).

Tab. I. Vancouver Scar Scale

\begin{tabular}{|c|c|c|}
\hline Characteristic of the scar & Type & Points \\
\hline \multirow[t]{4}{*}{ Vascularity } & Normal & 0 \\
\hline & Pink & 1 \\
\hline & Red & 2 \\
\hline & Purple & 3 \\
\hline \multirow[t]{6}{*}{ Pliability } & Normal & 0 \\
\hline & Supple & 1 \\
\hline & Yielding & 2 \\
\hline & Firm & 3 \\
\hline & Ropes & 4 \\
\hline & Contracture & 5 \\
\hline \multirow[t]{3}{*}{ Pigmentation } & Normal & 0 \\
\hline & Hypo & 1 \\
\hline & Hyper & 2 \\
\hline \multirow[t]{4}{*}{ Height } & Flat & 0 \\
\hline & $<2 \mathrm{~mm}$ & 1 \\
\hline & $2-5 \mathrm{~mm}$ & 2 \\
\hline & $>5 \mathrm{~mm}$ & 3 \\
\hline
\end{tabular}

Max. 13 points 
Tab. II. Discomfort related to the scar

\begin{tabular}{|c|c|c|c|c|}
\hline Type of discomfort & Lack of discomfort & Pain & Burning & Itching \\
\hline & 0 points & 1 points & 1 points & 1 points \\
\hline
\end{tabular}

Max. 3 points

Each of the patients participating in the study had a photograph of the scar taken with a millimetre scale and the code number assigned to the patient. Biological material in the form of a double swab from mucosa was collected from all participants using a PrepFiler Forensic DNA Extraction Kit (Applied Biosystems) for DNA research.

Polymorphism C(-509)T TGF- $\beta 1$ ( $r$ 1800469) was indentified by PCR-RFLP (polymerase chain reaction - restriction fragment length polymorphism) using specific primer pairs. The sense primer with the following sequence was used for amplification.

5'-CAGACTCTAGAGACTGTCAG-3'

And the antisense primer:

5'-GTCACCAGAGAAAGAGGAC-3'.

In the preliminary experiments the optimal PCR conditions were established. All amplifications were performed in thermocycler Mastercycler gradient (Eppendorf), in a volume $20 \mu$ l of reaction mixture containing:

- 40 ng genomic DNA,

- buffer PCR [10 mM Tris- $\mathrm{HCl}, 50 \mathrm{mM} \mathrm{KCl,} \mathrm{0.08 \%} \mathrm{Nonidet}$ P40] (MBI Fermentas),

- dNTP [200 mM] (MBI Fermentas),

- $\mathrm{MgCl}_{2}[1.5 \mathrm{mM}]$ (MBI Fermentas),

- 4 pmol sense and antisense primer (synt. TIB MOLBIOL, Poznań),

- $0.5 \mathrm{U}$ polymerase Taq (MBI Fermentas). PCR:

The following temperature-time profile was used in

- Phase I: initial denaturation $940^{\circ} \mathrm{C}-5 \mathrm{~min}$,

- Phase II (38 cycles):

- denaturation: $940^{\circ} \mathrm{C}-20$ seconds,

- hybridization of primers: $600^{\circ} \mathrm{C}-40$ seconds,

- elongation: $720^{\circ} \mathrm{C}-40$ seconds.

- Phase III: final elongation $720^{\circ} \mathrm{C}-8$ minutes.

The products of amplification (length $=419 \mathrm{bp}$ ) were subjected to restriction analysis with the enzyme Bsu36l $\left(37^{\circ} \mathrm{C} / 16 \mathrm{~h}\right)$. Within the amplified gene fragment TGF- $\beta 1$, allele $(-509) C$ has one restriction area for the enzyme Bsu36I, and as a result of digestion of the amplicon two restriction fragments of the $228 \mathrm{bp}$ and $191 \mathrm{bp}$ are created. Allele (-509)T does not have such a restriction site and the digestion of the amplicon forms a restriction fragment of 419 bp.

The obtained restriction forms were separated by electrophoresis on a $2 \%$ agarose gel with staining ethidium bromide. The separation was conducted in $1 \times$ TBE buffer (0.089 M Tris, 0.089 M boric acid, $2 \mathrm{mM}$ EDTA) at a temperature of $200^{\circ} \mathrm{C}$, at a voltage of $80 \mathrm{~V}$. The lengths of the restriction fragments were determined pursuant to the DNA marker pUC Mix Marker 8 (MBI Fermentas).

The final step was gel documentation using G:BOX BioImaging System (SYNGENE) (Fig. 3).

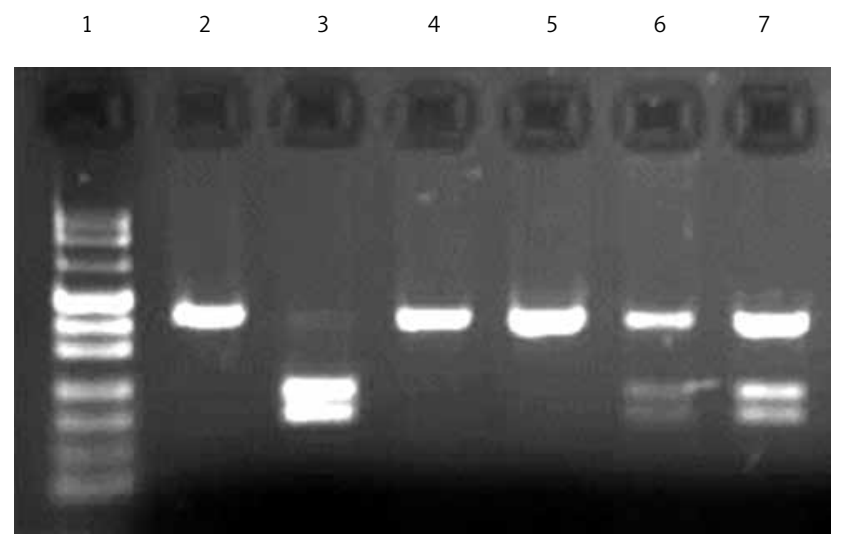

Electrophoretic separation of the restriction fragments. Paths: 1 - lengths of DNA marker - pUC Mix Marker 8 (MBI Fermentas), 2, 4, 5 - homozygotes TT, 3 - homozygous CC, 6, 7- heterozygotes CT

Fig. 3. Identification of polymorphism C(-509)T of TGF- $\beta 1$ gene by PCR-RFLP

\section{Statistical analysis}

The statistical significance of differences between qualitative variables was analysed with the exact two-sided Fisher test, and between measurable variables with the Kruskal-Wallis test or Mann-Whitney $U$ test. The value of the odds ratio (OR) and its 95\% confidence interval $(95 \% \mathrm{Cl})$ were used to assess the strength of the association between genotype and keloid formation. The logistic regression model was used in multivariate analysis. $P<0.05$ was taken into consideration as the threshold of statistical significance. The calculations were performed in Statistica 10 software.

\section{Results}

Of the 100 people who were examined, DNA was isolated in 73 patients ( 22 women and 51 men) aged between 38 to 84 . The average age was 64.75 and the standard deviation 9.37. The age was not significantly different ( $p=0.46$, Mann-Whitney $U$ test) between 36 patients with keloids (63.9 \pm 10.0 years) and 37 patients with healthy scars (65.6 \pm 8.7 years).

The percentage distribution of the genders in each group is presented in Table III. There were no significant differences between groups ( $p=1.0$, exact Fisher test).

Tab. III. Distribution of genders of the analysed groups of patients

\begin{tabular}{lccc} 
& Women & Men & Together \\
Keloids & 11 & 26 & 37 \\
& $29.73 \%$ & $70.27 \%$ & 36 \\
\hline Healthy scars & 11 & 25 & \\
\hline Total & $30.56 \%$ & $69.44 \%$ & 73 \\
\hline
\end{tabular}


Tab. IV. Distribution of frequency of genotypes and alleles of polymorphic TGF- $\beta 1 \mathrm{~T}(-506) \mathrm{C}$ in the analysed groups of patients

\begin{tabular}{|c|c|c|c|c|c|}
\hline Group & Homozygous CC & Heterozygote CT & Homozygous TT & Allele C & Allele T \\
\hline Healthy scars & $\begin{array}{c}9 \\
24.32 \% \\
\end{array}$ & $\begin{array}{c}19 \\
51.35 \%\end{array}$ & $\begin{array}{c}9 \\
24.32 \%\end{array}$ & $\begin{array}{c}37 \\
50.00 \% \\
\end{array}$ & $\begin{array}{c}37 \\
50.00 \%\end{array}$ \\
\hline Keloids & $\begin{array}{c}18 \\
50 \%\end{array}$ & $\begin{array}{c}14 \\
38.89 \%\end{array}$ & $\begin{array}{c}4 \\
11.11 \%\end{array}$ & $\begin{array}{c}50 \\
69.44 \%\end{array}$ & $\begin{array}{c}22 \\
30.56 \%\end{array}$ \\
\hline
\end{tabular}

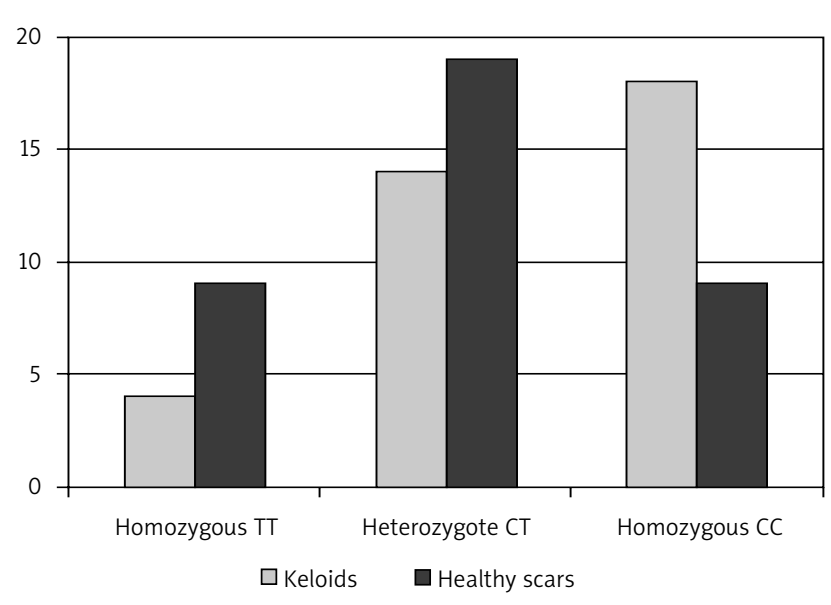

Fig. 4. Distribution of the number of TGF- $\beta 1$ polymorphisms T(506)C in the analysed groups of patients

The act of isolating DNA failed in 27 patients. The incorrect way of taking the samples, e.g. too small amount of DNA or improper storage condition of the swabs, could be the cause of the failure.

The results of the analysis of the polymorphism C(-509)T TGF- $\beta 1$ are presented in Table IV. The distribution of genotypes was consistent with the Hardy-Weinberg law ( $p=$ 0.70 and $p=1.0$ ) in both groups, in the test as well as in the control group (Fig. 4).
There was no relationship between the genotype and the age of the patients ( $p=0.48$, Kruskal-Wallis test). In contrast, a significant correlation between genotype and the occurrence of keloids was observed: the presence of allele T (i.e. CT or TT genotype) was related to significantly lower risk of keloid formation $(\mathrm{OR}=0.32)$. The dependence of the various alleles and genotypes relative to each other is presented in Table $\mathrm{V}$.

\section{Discussion}

Scar formation is a physiological process which enables healing of wounds. In some cases excessive overgrowth of scar tissue occurs while the wounds are healing. It extends beyond the area of the wound and causes severe pain and itching and a keloid develops.

The frequency of the occurrence of keloids is estimated from $5 \%$ to $16 \%$, particularly in people with dark skin colour. The is no single effective method of treating keloids $[3,16]$, and all those previously used such as surgical removal, laser therapy, cryotherapy, pressotherapy, injecting, corticosteroids, radiation or the use of silicone materials only allow one to minimize the size of the scar and related ailments. If it cannot be effectively treated, can it be prevented?

There are literature reports of a relationship between keloid disease and changes in DNA where the mutations and polymorphisms of various genes may influence the de-

Tab. V. The relationship between genotype TGF- $\beta 1 \mathrm{~T}(506) \mathrm{C}$ and the presence of keloid

\begin{tabular}{llll} 
Compared genotypes & $\begin{array}{c}\text { Odds ratio for presence of keloid } \\
\text { TGF- } \beta 1 \text { T }(506) \text { C }\end{array}$ & $\begin{array}{c}\text { Confidence interval OR } \\
95 \% \mathrm{Cl}\end{array}$ & $\begin{array}{c}P \\
\text { TT + CT vs. CC }\end{array}$ \\
\hline TT vs. CT + CC & 0.3214 & $0.1188-0.8697$ & 0.030 \\
\hline TT vs. CC & 0.3889 & $0.1079-1.4020$ & 0.046 \\
\hline T vs. C & 0.2222 & $0.0535-0.9229$ & 0.019 \\
\hline CT vs. CC & 0.4400 & $0.2235-0.8664$ & 0.073 \\
\hline TT vs. CT & 0.3684 & $0.1281-1.0600$ & 0.52 \\
\hline
\end{tabular}

It was found in the multivariate analysis (Table VI) that the presence of the allele T (i.e. CT or TT genotype) was related to a significantly lower risk of keloid formation $(O R=0.32)$, regardless of age and gender.

Tab. VI. Multivariate analysis in the logistic regression model of the relationship between age, gender and carrier of allele TGF- $\beta 1$ (-509)T (genotypes CT or TT) with the presence of keloid

\begin{tabular}{lccc} 
Independent variables & OR & $95 \% \mathrm{Cl}$ & $p$ \\
Age (years) & 0.9773 & $0.9276-1.0296$ & 0.38 \\
\hline Gender (male) & 0.9225 & $0.3186-2.6712$ & 0.88 \\
\hline Carrier of allele TGF- $\beta 1(-509) T$ & 0.3153 & $0.1136-0.8746$ & 0.024 \\
\hline
\end{tabular}


velopment of keloid disease [1, 2, 6-10, 17]. There are also studies which find no relationship between gene polymorphism of TGF- $\beta 1$ and keloid disease [11].

Regarding the different reported studies, we attempted to find out whether by analysing the specific gene TGF- $\beta 1$ and obtaining the specific genotype of a person we can determine the risk of keloid formation.

On the basis of the results demonstrated above, the relationship between occurrence of nucleotide $T(-509)$ TGF- $\beta 1$ and decreased risk of developing keloid scars was proven. This would help to identify patients who in the case of any interference (trauma or surgery) are prone to additional complications, i.e. the development of keloids. Having such knowledge before the scheduled surgery, a method of operating with minimum invasiveness (e.g. laparoscopy) could be used.

The results encourage further genetic research aimed at searching for new mutations and polymorphisms of the specific genes responsible for the development of keloids. It would allow us to predict the development of keloid disease and its course and, as a result, to treat it successfully and to prevent it in the future.

\section{Conclusions}

1. On the basis of this analysis, it was found that the presence of allele I at position -509 of the gene TGF- $\beta 1$ is associated with a lower risk of keloid formation.

2. The age of the patients participating in the study did not differ significantly between the groups and did not influence the risk of keloids.

3. No evidence of a relationship between the gender of patients and risk of developing keloid disease was found.

\section{Disclosure}

The authors report no conflict of interest.

\section{References}

1. Shih B, Bayat A. Genetics of keloid scarring. Arch Dermatol Res 2010; 302: 319-339.

2. Brown JJ, Bayat A. Genetic susceptibility to raised dermal scarring. Br J Dermatol 2009; 161: 8-18.

3. Marneros AG, Krieg T. Keloids - clinical diagnosis, pathogenesis, and treatment options. J Dtsch Dermatol Ges 2004; 2: 905-913.

4. Shih B, Garside E, McGrouther DA, Bayat A. Molecular dissection of abnormal wound healing processes resulting in keloid disease. Wound Repair Regen 2010; 18: 139-153.

5. Chike-Obi CJ, Cole PD, Brissett AE. Keloids: pathogenesis, clinical features, and management. Semin Plast Surg 2009; 23: 178-184.

6. Tuan TL, Nichter LS. The molecular basis of keloid and hypertrophic scar formation. Mol Med Today 1998; 4: 19-24.

7. Char F. Ehlers-Danlos syndrome. Birth Defects Orig Artic Ser 1971; 7: 300-302.

8. Goeminne L. A new probably X-linked inherited syndrome: congenital muscular torticollis, multiple keloids cryptorchidism and renal dysplasia. Acta Genet Med Gemellol (Roma) 1968; 17: 439-467.

9. Siraganian PA, Rubinstein JH, Miller RW. Keloids and neoplasms in the Rubinstein-Taybi syndrome. Med Pediatr Oncol 1989; 17: 485-491.

10. Gonzalez-Martinez R, Marin-Bertolin S, Amorrortu-Velayos J. Association between keloids and Dupuytren's disease: case report. Br J Plast Surg 1995; 48: 47-48.

11. Bayat A, Bock O, Mrowietz U, Ollier WE, Ferguson MW. Genetic susceptibility to keloid disease and hypertrophic scarring: transforming growth factor beta1 common polymorphisms and plasma levels. Plast Reconstr Surg 2003; 111: 535-543.

12. Bayat A, Bock O, Mrowietz U, Ollier WE, Ferguson MW. Genetic susceptibility to keloid disease and transforming growth factor beta 2 polymorphisms. Br J Plast Surg 2002; 55: 283-286.

13. Bayat A, Walter JM, Bock O, Mrowietz U, Ollier WE, Ferguson MW. Genetic susceptibility to keloid disease: mutation screening of the TGFbeta3 gene. Br J Plast Surg 2005; 58: 914-921.

14. Krzemień S, Knapczyk P. Aktualne poglądy dotyczące znaczenia transformującego czynnika wzrostu b (TGF-b) w patogenezie niektórych stanów chorobowych. Wiad Lek 2005; 58: 536-539.

15. Stępień-Wyrobiec O, Hrycek A, Wyrobiec G. Transformujący czynnik wzrostu beta (TGF-beta) - budowa, mechanizmy oddziaływania oraz jego rola w patogenezie tocznia rumieniowatego układowego. Postępy Hig Med Dosw (online) 2008; 62: 688-693.

16. Osiak K. Przerostowe blizny, bliznowce i przykurcze bliznowate. Post Nauk Med 2005; 18: 17-23.

17. Pastuszak-Gabinowska M, Peregud-Pogorzelski J, Łuksza K, Sznelewski P, Brodkiewicz A. Wybrane aspekty molekularnych podstaw tworzenia się bliznowców. Roczniki Pomorskiej Akademii Medycznej w Szczecinie 2011; 57: 10-17. 